$\mathbb{T}$ periodica polytechnica

\author{
Social and Management Sciences \\ $16 / 1(2008) 45+54$ \\ doi: 10.3311/pp.so.2008-1.05 \\ web: http://www.pp.bme.hu/so \\ (c) Periodica Polytechnica 2008
}

RESEARCH ARTICLE

\section{Criteria groups in the eco-labelling process system - comparative analysis focused on the Hungarian system}

\author{
Rita Baranyi
}

Received 2008-09-14

\begin{abstract}
In this paper the product groups and criteria systems in ecolabelling process are brought into focus, as these are one of the main elements of the whole process. The article concentrates at the main stakeholders of the eco-labelling process and the advantages of eco-labelling focusing on the relationship and role of product groups and criteria systems. Therefore the paper presents that the first step of the eco-labelling process is to define product groups and work out criteria systems for the product or service (hereon referred to as: the product). It is important to choose product groups that play a major role on the market and that they have a possibility of minimizing their impacts on the environment (based on life cycle approach) during the entire life cycle. The second part of the article presents the conclusions of a comparative analysis of criteria systems of the Hungarian, $E U$, Nordic and German eco-labelling systems, focussing on the Hungarian system. The research was carried out with the aim to get information that can increase the efficiency of the Hungarian system in the future.
\end{abstract}

\section{Keywords}

Eco-labelling - eco-label · Life Cycle Assessment (LCA) . stakeholders and advantages of eco-labelling · product groups . criteria systems $\cdot$ producer $\cdot$ costumer $\cdot$ environment $\cdot$ ecolabelling organization

\section{Rita Baranyi}

Department of Environmental Economics, BME, Budapest, 1111, Stoczek u. 2, Hungary

e-mail: ritabaranyi@gmail.com

\section{Introduction}

The aim of the article is to present the importance of criteria systems in the eco-labelling process. The first part of the article gives a general overview of the eco-labelling process, stakeholders and relationship systems in general, but also focuses on the role of the criteria systems. The second part of the article shows the advantages of eco-labelling generally and also shows how criteria systems can influence these advantages. In the third part, the results of a comparative analysis are presented. This research focussed on the comparison of national eco-labelling systems with each other, with the aim of obtaining new professional results that can be used in the Hungarian eco-labelling system in order to make the Hungarian system more efficient.

\section{Eco-labelling process: stakeholders, relationship systems}

Eco-labelling is a voluntary method of environmental performance certification (GEN, 2004). Enterprises can use eco-labels as a means of communication which shows that the product bearing the eco-label has less impact on the environment during their whole life cycle, 'from cradle to cradle', in comparison with other similar products or services. It is guaranteed by independent eco-labelling organizations to define product groups, work out criteria systems and evaluate applications. If the application is successful the product may use the eco-label thereafter.

There are several eco-labels in the world. These are often national labels (e.g. Hungarian, German) and sometimes are international (EU - valid in the EU member states, Nordic - valid in Denmark, Finland, Iceland, Sweden, Norway). The systems are different but the main process of the eco-labelling is the same in every system. The Fig. 1 1 shows a schematic overview of the eco-labelling process, showing the main stakeholders and the relationship between the stakeholders. This figure is based on the result of the analyses of several national and international eco-labelling systems.

As it can be deduced from the figure, three main stakeholder groups can be identified during the eco-labelling process: the producers, the eco-labelling organization and the consumers. 


\section{Eco-labelling process - stakeholders - relationship system}

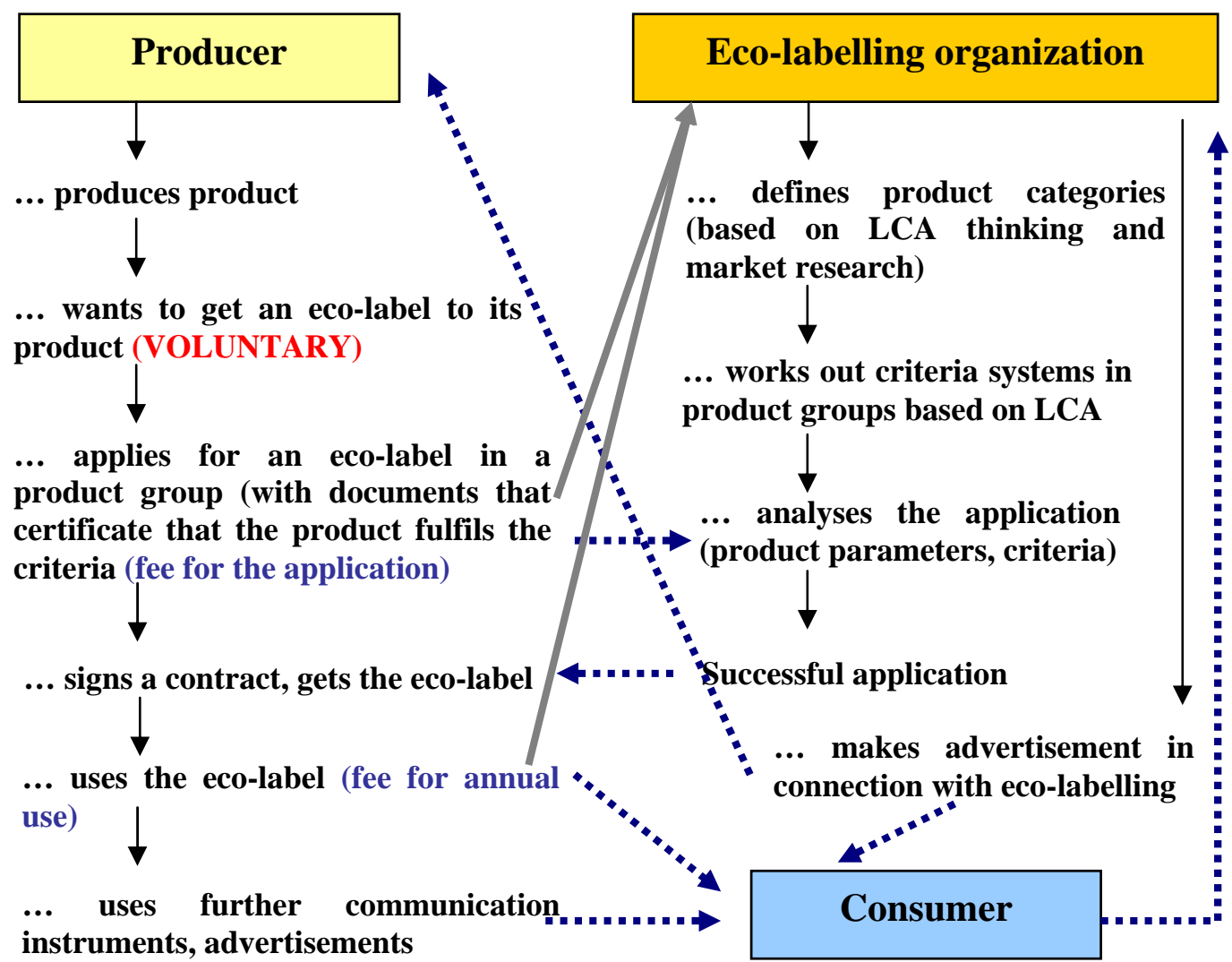

Fig. 1. The stakeholders and relationship system of eco-labelling

\section{Producers}

The producer of the product or service that has a smaller environmental impact has the possibility to choose an eco-label as a voluntary environmental communication tool if the product group which the product belongs to is included in the ecolabelling criteria system. The eco-labelling systems have just few special product groups, therefore not all producers can apply for an eco-label. During the application process the producer has to prove that the product fulfils the requirements of the criteria system, by means of documents, analyses and measurements.

If the application is successful, the producer signs the contract and may use the eco-label on its product and in advertisements.

\section{Eco-labelling organization}

The first task of an eco-labelling organization is to define product categories based on LCA thinking and market research. The second step is to work out criteria systems in products groups based on LCA. The third step of the process is to evaluate the applications of the producers. An important task of the eco-labelling organization is to plan and realize an efficient marketing strategy of the eco-label (e. g. publications, brochures, information campaigns, raising awareness, games, etc.).

\section{Conumers}

Consumers as end-users are passive stakeholders in the ecolabelling process but they can be driving force if they buy products with eco-label.

\section{Relationship systems - Money, information Money}

Producers have to pay a fee for the application (application fee) and for using the label (fee for annual use) to the organization. These fees partially cover the costs of the eco-labelling organizations.

\section{Information}

As it can be seen from Fig. 1 the stakeholders are in relationship with each other in the eco-labelling process. These are different but the basis of relationships is the information flow between the stakeholders. The information streams are the following:

- Application for the eco-label (written documents) Information stream: from producer to eco-labelling organization

- Successful application

Information stream: from eco-labelling organization to producer 


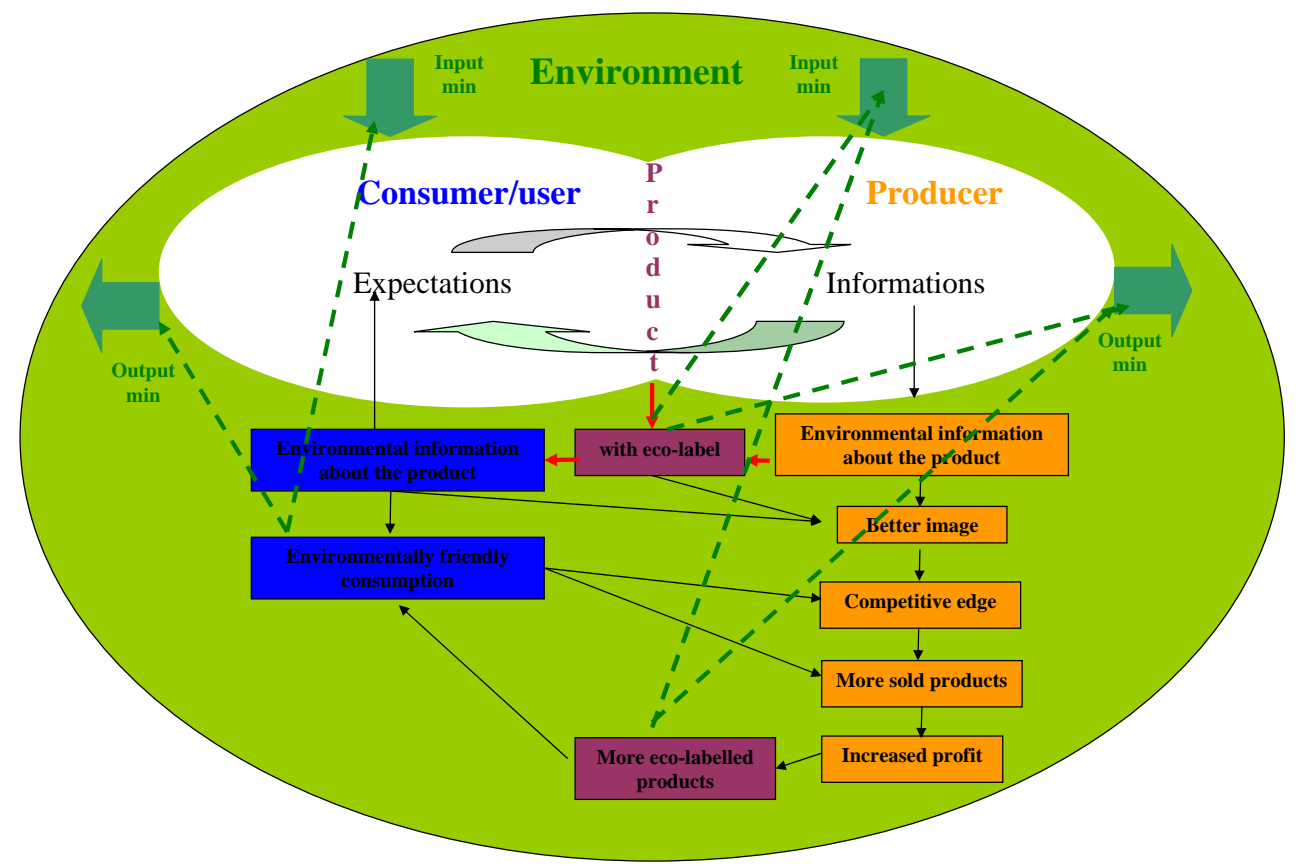

(Source: own edition)

Fig. 2. Advantages of eco-labelling

- Eco-label on the product

Information stream: from producer to consumer

- Further communication instruments, advertisements Information stream: from producer to consumer

- Collecting information, market research Information stream: from consumer to eco-labelling organization

- Marketing strategy in connection with the label (e. g. publications, brochures, information giving campaigns, plays etc.)

Information stream: from eco-labelling organization to producer and consumer

The most important information streams are the last four items on the list. In theory, the eco-label is a success factor, and in order to be that in practice too, an effective communication between the stakeholders is necessary (Der Blaue Engel. 2007). Without sufficient relevant information:

- the eco-labelling process will be ad-hoc, because the organization can not choose the important product groups;

- the consumer and producer will not know the eco-labelling process and what the eco-label means;

- they will not see the advantages of the labelling;

- the producer will not want to apply for the eco-label;

- the consumer will not choose eco-labelled products over regular products.
Discussion: What is the role of the criteria systems in the eco-labelling process?

As it was mentioned above product groups and criteria systems of an LCA approach are the basis of the application. Without criteria systems, producers cannot apply for the eco-label. The eco-labelling organization has to establish a criteria system. A criteria system can be efficient if the organization takes into consideration the expectations of producers, consumers and the environmental impacts during the criteria making process. Wellchosen product groups and criteria systems can help the success of advantages of the labelling process (further information in parts 3,4).

\section{Advantages of eco-labelling}

As it was mentioned before, the effective communication during the eco-labelling process was important, because without communication the advantages of labelling can not be achieved. In this chapter the advantages of eco-labelling are discussed and presented based on Fig. 22. The aim of this developed model is to show the 3 win relationship system in the dimension of sustainability, presenting the advantages in one common figure.

Eco-labels can be an instrument of the environmental regulatory system and can also be a voluntary environmental management tool. Eco-labels are success factors in environmental regulation, because if the system functions effectively, advantages can be identified in all three dimensions of sustainability: social, economic and environmental.

The figure shows the three dimensions:

- society as a consumer / user;

- economy as a producer;

- environment. 
The common part between the consumer and producer is the product (in the middle of the figure). In this assessment the product plays the main role because the product can get an eco-label, and the product connects the producer with the consumer.

Consumers have a lot of expectations in connection with the product. They want to get information about the environmental aspects of the product. The producer wants to live up of the society's expectations therefore it has to choose a communication tool (e.g. eco-label) in order to communicate the expected information.

If the product can get the eco-label it means that the product meets the criteria. As the criteria systems are developed by eco-labelling organization based LCA thinking, contain environmental criteria in all of the life cycle stages (extraction and process of raw materials, production, transport and distribution, use, reuse, recovery and disposal of products). Therefore we can say: the product with eco-label has less environmental impacts as a product with same function without eco-label. It means that the producers can minimize the input and output streams of the processes during the whole life cycle of the product. Fig. 2 present that possibility by the arrows from the eco-label to input and output minimizing of production.

$\bullet$

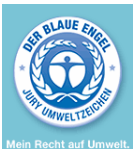

German system: 'The blue Angel' - from 1977

$\bullet$

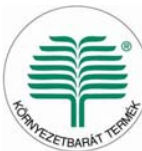

Hungarian system: 'Green oak’ - from 1993

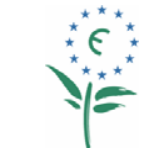

EU system: ‘EU flower’ - from 1992

$\bullet$

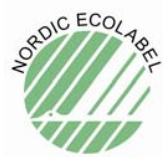

Nordic system: ‘The Swan’ - from 1989

(Source: http://www.svanen.nu/, http://www.blauer-engel.de, http://www.kornyezetbarat-termek.hu/, http://ec.europa.eu/environment/ecolabel/index_en.htm)

Fig. 3. Eco-labelling systems

If consumers get environment related information about the product (e.g. by using eco-label) and they are environmentally conscious, it is expected that consumers will choose the environmental friendly product with an eco-label over others. It is also the base of green consumer behaviour that has advantages to the environment with minimizing inputs and outputs of the consumptions. In Fig. 2 this possibility is presented by the arrows from the environmental friendly consumption to input and output minimizing of consumption.

Moreover if a consumer sees the product with an eco-label, his attitude towards the product and producer can change positively which can influence the image of the producer. If environmentally friendly consumption develops and consumers choose products with eco-labels over other products, the producers of eco-labelled products can gain a competitive edge on the market. With this competitive edge, the producer can sell more products and can obtain an increased profit. If the producers see the ecolabel as a real advantage in the marketing processes, it can be expected that the producer will be urged to produce and sell more eco-labelled products. This in turn means a further reduction in environmental impacts. This possibility is presented by the arrows from the more eco-labelled products to input and output minimizing of producing in Fig. 2 .

Discussion: How can product groups and criteria systems influence the effectiveness of eco-labelling?

As it was mentioned above it is necessary to choose product groups with which the consumers have the possibility of green consumer behaviour with choosing the labelled product that can be also driving force to the producer to apply for the label. Moreover LCA thinking criteria systems give the possibility to decrease environmental aspects and impacts.

Arguably the advantages of eco-labelling are the following [3]:

- To the environment: Environmental impacts decrease

- Basis of advantage: Product criteria systems based on LCA thinking (eco-labelling organization)

Information about eco-labels (eco-labelling organization, producers)

Eco-labelled products on the market (producers)

Environmentally friendly consumption (consumers)

- To the producer: Better image, Competitive edge, Increased profit

- Basis of advantage: Product criteria system in the produced product group (eco-labelling organization)

Information about eco-labels (eco-labelling organization)

Environmentally friendly consumption (consumers)

- To the consumer: Environmental information about the product, alternative in the product choice

- Basis of advantage: Information about eco-labels (ecolabelling organization, producers)

Eco-labelled products on the market (producers)

A lot of factors can be seen on the list that influence the effectiveness of eco-labelling in practice. This paper focuses on the role of the criteria systems therefore in the next chapter the role of criteria systems are studied in a comparative analysis in that the criteria systems of four eco-labelling systems (the Hungarian, EU, Nordic and German) were examined. 


\section{Criteria groups in different eco-labelling systems}

As it was mentioned above the product groups and the criteria system can influence and determine the efficiency of the eco-labelling. In practice, in the Hungarian system several of the listed advantages are not achieved, (whereas they are in the other three analysed systems) in practice. In my point of view the causes are to be found in the criteria making process. The aim of the research is to get answer (quantitative results) to the question if the Hungarian criteria system differs from the others or not. Therefore in the research qualitative and quantitative information about the product groups and criteria systems are analysed.

These results and the information about the favourite criteria can be used in the future in order to grow the efficiency of the Hungarian eco-labelling system and utilize the 3 win relationship (as mentioned in Part 3) in practice.

As the criteria systems are the basic elements of eco-labelling, in this article four eco-labelling systems were chosen and analysed. These are the Hungarian, EU, Nordic and German systems. Two of them are national systems (Hungarian, German), two of them are international systems (EU - available in the EU member states, Nordic - available in Denmark, Finland, Iceland, Sweden, Norway).

Why are the product groups and criteria systems in the eco-labelling process important?

- To the environment: it is useful to choose product groups which contain the possibility to improve the environmental life cycle of the product and reduce the input and output streams.

- To the producer: it is useful to choose product groups whose environmentally friendly features can yield a better image, competitive edge and increased profit on the market, so the product groups can be competitive on those markets.

- To the consumer: it is important to choose product groups that are everyday products and the consumers have the possibility to choose the environmentally friendly product over others.

For example in the EU system there was a prioritisation methodology developed for choosing product groups (Prioritisation Methodology, EU):

Environmental questions: Does the product group have ....

1 significant environmental impacts on a global, regional or general basis?

2 significant potential for environmental improvement through consumer choice?

3 relevance to priority environmental policy areas, instruments and legislation (e.g. IPP, waste, climate change, energy label)?

Market related questions: Does the product group ...
4 represent a significant volume of sales and trade in the internal market?

5 provide opportunities and incentives to manufacturers and/or retailers to seek a competitive advantage by offering ecolabelled products?

6 have environmental arguments already associated with its marketing?

7 meet explicit stakeholder interest for an eco-label for this product group?

8 have a significant volume of sales for final use or consumption?

9 have a significant public procurement market?

10 have a significant private procurement market for this product group?

11 come from small manufacturers?

12 have a high rate of purchase by consumers (e.g. every day or every week)?

13 support an existing product group "family"?

14 present a particular opportunity to enhance the scheme's overall visibility?

Other related issues: Does the product group ...

15 involve consumer health and safety issues?

16 exist within another eco-label schemes in Europe or elsewhere, and if so, is the product group a success within that scheme?

17 have established fitness for use standards?

The next paragraphs discuss the criteria systems of the analysed eco-labelling systems and conclusions of the comparative analysis.

As the aim of the comparative analysis is to give quantitative and qualitative information about the used criteria in the analysed national systems the first step of the analysis was the collecting of criteria systems of the eco-labelling systems. That step gives qualitative information about the criteria. The second step was to develop a classification system with the aim to make common product groups that can be the base of the quantitative comparative analysis. It was needed because in the eco-labelling systems there are a lot of several criteria groups that can not be compared in an analysis.

10 main product groups and 8 sub-groups (Table 1) have been chosen. The classification was not easy, because often in the different systems there are criteria systems that can be classified into more main or sub-group. For example the computers: computers can be classified to the household products but also into the office products. The computers have been put to the office product group. 


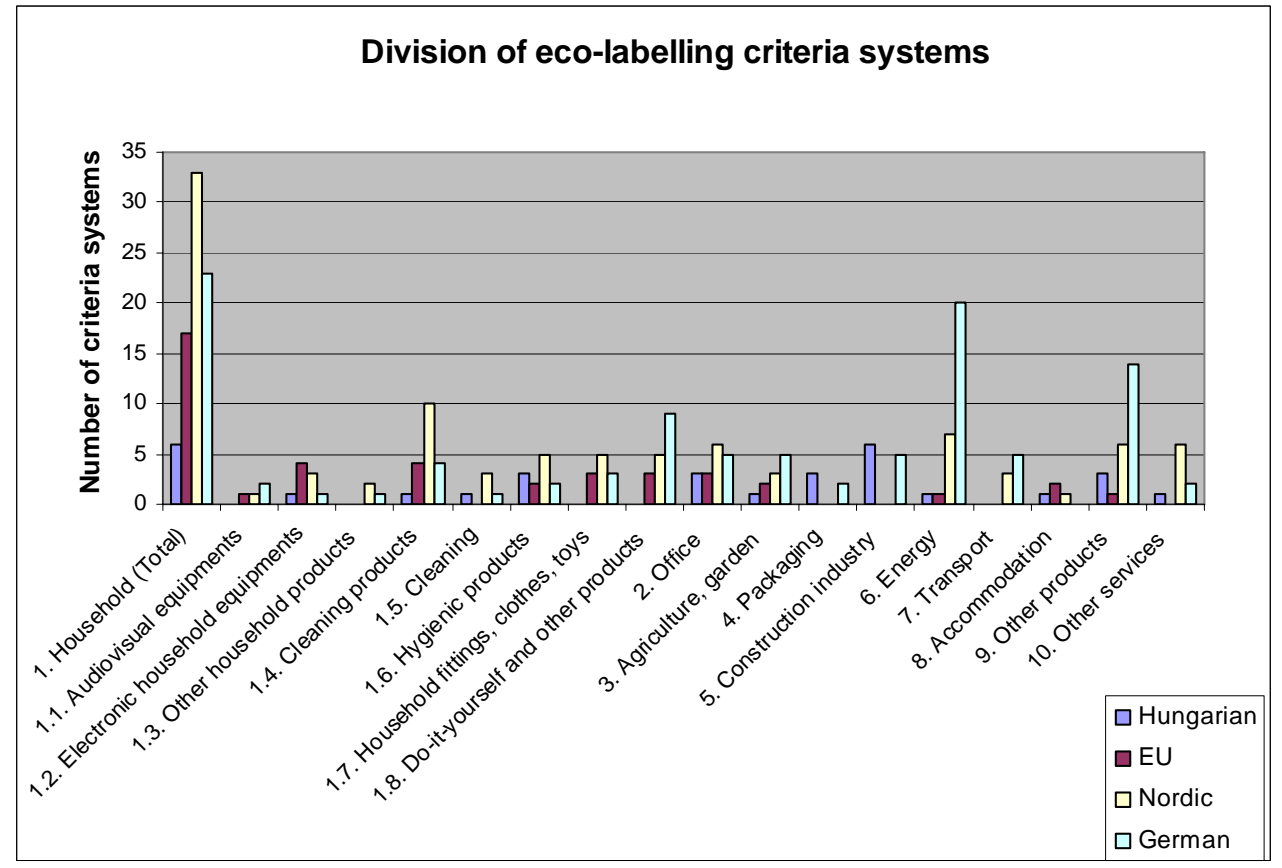

(Source: own edition)

Fig. 4. Division of eco-labelling criteria systems by product/service group

Table 1 contains the valid criteria systems of the eco-labelling systems. The German system has the most criteria (81), followed by the Nordic (66), the EU (26), whereas the Hungarian system has the fewest (24).

Fig. 4 contains the classification of criteria systems in a diagram:

It can be seen from the diagram that most criteria systems are in the household group. It is a good sign, because there is the possibility to choose environmentally friendly product during the building of house (e.g. do-it-yourself and other products), during the furnishing of house (e.g. household fittings) and in the every day shopping (e.g. cleaning-, hygienic products, clothes, toys).

There are other two groups that are in strong connection with the household: garden (agriculture, garden) and energy. In the garden group are criteria systems in connection with garden machinery and other tools that can be used in the household, in the garden. In the energy group are criteria systems in connection with heating systems that can also be used in the household. The next figures show the division of criteria systems in the ecolabelling systems.

In the Hungarian system the most criteria systems are in:

- Household; Construction industry - $24 \%$

- Office; Packaging; (Other products) - $12 \%$

In the German system the most criteria systems are in:

- Household - $29 \%$

- Energy - $26 \%$

- (Other products - $17 \%$ )
- Office; Construction industry; Agriculture, Garden; Transport $-6 \%$

In the EU system the most criteria systems are in:

- Household - $64 \%$

- Office - $12 \%$

- Agriculture; Accommodation - $8 \%$

In the Nordic system the most criteria systems are in:

- Household - 50\%

- Energy - $11 \%$

- Office, (Other products; Other services) - $9 \%$

Discussing the results the household category has the most criteria systems in every eco-labelling system. That is a good factor in the eco-labelling process because these are the products that can yield advantages for producer, customer and environment (as it was mentioned in part 3).

The quantitative analysis has given the result that in the Hungarian system the construction industry is the first place, too but in the other system the construction industry does not play so important role.

In the background of this anomaly the result can be that in the Hungarian system the criteria making process differs from the method shown above (prioritisation methodology) and the ecolabelling organization yields to the pressure of producers and develops new criteria that can not succeed the listed advantages of eco-labelling as regards that in so created product groups customer do not have the possibility to green consumer behaviour 
Tab. 1. Division of eco-labelling criteria systems by product/service group

\begin{tabular}{lllll}
\hline & Hungarian & EU & Nordic & German \\
\hline 1. Household (Total) & 6 & 17 & 33 & 23 \\
1.1. Audiovisual equipments & 0 & 1 & 1 & 2 \\
\%midrule 1.2. Electronic household equipments & 1 & 4 & 3 & 1 \\
\%midrule 1.3. Other household products & 0 & 0 & 2 & 1 \\
1.4. Cleaning products & 1 & 4 & 10 & 4 \\
1.5. Cleaning & 1 & 0 & 3 & 1 \\
1.6. Hygienic products & 3 & 2 & 5 & 2 \\
1.7. Household fittings, clothes, toys & 0 & 3 & 5 & 3 \\
1.8. Do-it-yourself and other products & 0 & 3 & 5 & 9 \\
2. Office & 3 & 3 & 6 & 5 \\
3. Agriculture, garden & 1 & 2 & 3 & 5 \\
4. Packaging & 3 & 0 & 0 & 2 \\
5. Construction industry & 6 & 0 & 0 & 5 \\
6. Energy & 1 & 1 & 7 & 20 \\
7. Transport & 0 & 0 & 3 & 5 \\
8. Accommodation & 1 & 2 & 1 & 0 \\
9. Other products & 3 & 1 & 6 & 14 \\
10. Other services & 1 & 0 & 6 & 2 \\
Total: & $\mathbf{2 4}$ & $\mathbf{2 6}$ & $\mathbf{6 6}$ & $\mathbf{8 1}$ \\
\hline
\end{tabular}

(Source: own edition based on data of eco-labelling systems)

\section{Division of eco-labelling criteria systems (Hungarian system)}

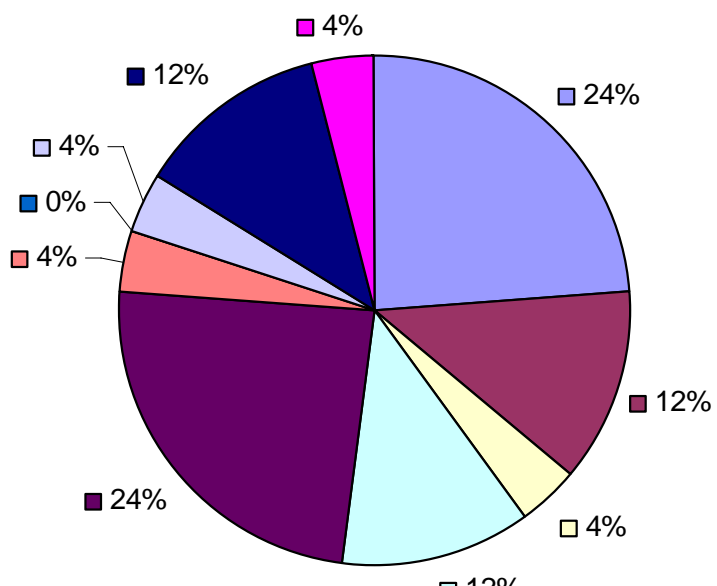

\begin{tabular}{|l|}
\hline 1. Household \\
$\square$ 2. Office \\
$\square$ 3. Agriculture, garden \\
$\square$ 4. Packaging \\
$\square$ 5. Construction industry \\
$\square$ 6. Energy \\
$\square$ 7. Transport \\
$\square$ 8. Accommodation \\
$\square$ 9. Other products \\
10. Other services
\end{tabular}

$\square 12 \%$

(Source: own edition)

Fig. 5. Division of criteria systems by product/service group (Hungarian system)

and really influencing capacity. Construction industry is one of them.

The next step of the analyses was the comparison of the criteria systems group by group. The aim was to get answer to the question what are the same criteria systems in the different eco-labelling systems. In Table 2 there are 37 analyzed criteria systems, these are the criteria system that are common in minimum two eco-labelling systems.

From the table it can be seen that in the eco-labelling systems are just 2 criteria systems (Household hygienic paper products, Copy and printing paper) that are common in all the four sys- tems, there are 10 criteria systems that are common in three ecolabelling systems, and 25 that are common in two eco-labelling systems.

The Hungarian system has 4 criteria systems that are common with one other eco-labelling system, and another 5 criteria systems that are common with two other eco-labelling systems. The EU system has 8 criteria systems that are common with one other, and 8 criteria systems that are common with other two eco-labelling systems. The Nordic system has 22 criteria systems that are common with one other, and 10 criteria systems that are common with other two eco-labelling systems. The Ger- 
Tab. 2. Summary of the common criteria systems of the Hungarian, EU, Nordic and German eco-labelling systems

\begin{tabular}{|c|c|c|c|c|}
\hline & Hungarian & EU & Nordic & German \\
\hline \multicolumn{5}{|l|}{ 1. Household } \\
\hline \multicolumn{5}{|l|}{ 1.1. Audiovisual equipments } \\
\hline Audiovisual equipment 1 & 0 & 1 & 1 & 0 \\
\hline \multicolumn{5}{|c|}{ 1.2. Electronic household equipments } \\
\hline Refrigerators and freezers 2 & 1 & 1 & 1 & 0 \\
\hline Dishwashers 3 & 0 & 1 & 1 & 0 \\
\hline Washing machines 4 & 0 & 1 & 1 & 0 \\
\hline \multicolumn{5}{|l|}{ 1.3. Other household products } \\
\hline Filters 5 & 0 & 0 & 1 & 1 \\
\hline \multicolumn{5}{|l|}{ 1.4. Cleaning products } \\
\hline General cleaning products 6 & 1 & 1 & 1 & 0 \\
\hline Dishwasher detergents 7 & 0 & 2 & 3 & 0 \\
\hline Laundry detergents8 & 0 & 1 & 2 & 0 \\
\hline \multicolumn{5}{|l|}{ 1.5. Cleaning } \\
\hline Micro-fibre clothes and mops 9 & 1 & 0 & 1 & 0 \\
\hline \multicolumn{5}{|l|}{ 1.6. Hygienic products } \\
\hline Household hygienic paper products 10 & 1 & 1 & 1 & 1 \\
\hline Shampoo, conditioner, body shampoo, liquid and solid soap. ..11 & 0 & 1 & 1 & 0 \\
\hline Hygienic products 12 & 1 & 0 & 1 & 0 \\
\hline \multicolumn{5}{|c|}{ 1.7. Household fittings, clothes, toys } \\
\hline Mattresses 13 & 0 & 1 & 0 & 1 \\
\hline Textiles, skins, leather, clothes 14 & 0 & 1 & 1 & 0 \\
\hline Furniture and fitments 15 & 0 & 0 & 1 & 1 \\
\hline \multicolumn{5}{|l|}{ 1.8. Do-it-yourself and other products } \\
\hline Floorings 16 & 0 & 1 & 1 & $2+1$ \\
\hline Paints and varnishes 17 & 0 & 1 & 1 & 2 \\
\hline Adhesives18 & 0 & 0 & 1 & 1 \\
\hline Wallpapers and Woodchip Wall Coverings 19 & 0 & 0 & 1 & 1 \\
\hline \multicolumn{5}{|l|}{ 2. Office } \\
\hline Computers20 & 0 & 2 & 1 & 1 \\
\hline Copying machines, printers, fax machines and multifunctional devices21 & 1 & 0 & 1 & 1 \\
\hline Copy and printing paper22 & 1 & 1 & 1 & 1 \\
\hline Toner cartridges 23 & 1 & 0 & 1 & 1 \\
\hline Paper envelopes 24 & 0 & 0 & 1 & 1 \\
\hline \multicolumn{5}{|l|}{ 3. Agriculture, garden } \\
\hline Compostable Plant Containers and plastic products 25 & 1 & 0 & 0 & 1 \\
\hline Machines for parks and gardens 26 & 0 & 0 & 1 & 1 \\
\hline \multicolumn{5}{|l|}{ 4. Packaging } \\
\hline Cardboard27 & 1 & 0 & 0 & 1 \\
\hline \multicolumn{5}{|l|}{ 5. Construction industry } \\
\hline 28 & 0 & 0 & 0 & 0 \\
\hline \multicolumn{5}{|l|}{ 6. Energy } \\
\hline Heat pumps29 & 0 & 1 & 1 & 2 \\
\hline Rechargeable Batteries30 & 0 & 0 & 1 & 1 \\
\hline Boilers and burners for liquid and gas 31 & 0 & 0 & 1 & 10 \\
\hline Solid bio fuel boilers32 & 0 & 0 & 1 & 2 \\
\hline \multicolumn{5}{|l|}{ 7. Transport } \\
\hline Vehicle tyres33 & 0 & 0 & 1 & 1 \\
\hline \multicolumn{5}{|l|}{ 8. Accommodation } \\
\hline Accommodation34 & 1 & 2 & 1 & 0 \\
\hline \multicolumn{5}{|l|}{ 9. Other products } \\
\hline Lubricants35 & 0 & 1 & 1 & 2 \\
\hline De-icers36 & 0 & 0 & 1 & 1 \\
\hline \multicolumn{5}{|l|}{ 10. Other services } \\
\hline Hand towel roll services 37 & 0 & 0 & 1 & 1 \\
\hline Printing companies38 & 0 & 0 & 1 & 1 \\
\hline
\end{tabular}

(Source: own edition based on data of eco-labelling systems) 


\section{Division of eco-labelling criteria systems \\ (German system)}

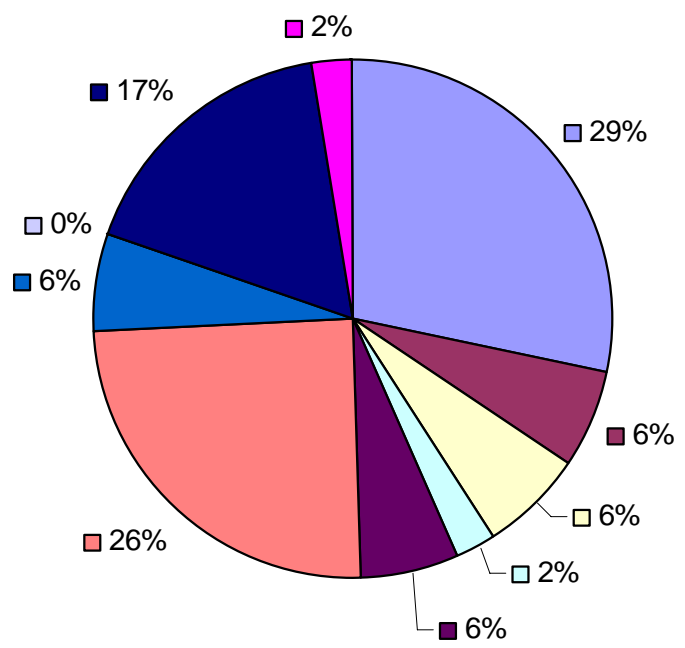

\begin{tabular}{|l|}
$\square$ 1. Household \\
$\square$ 2. Office \\
$\square$ 3. Agriculture, garden \\
$\square$ 4. Packaging \\
$\square$ 5. Construction industry \\
$\square$ 6. Energy \\
$\square 7$. Transport \\
$\square$ 8. Accommodation \\
$\square 9$. Other products \\
$\square$ 10. Other services \\
\hline
\end{tabular}

(Source: own edition)

Fig. 6. Division of eco-labelling criteria systems by product/service group (German system)

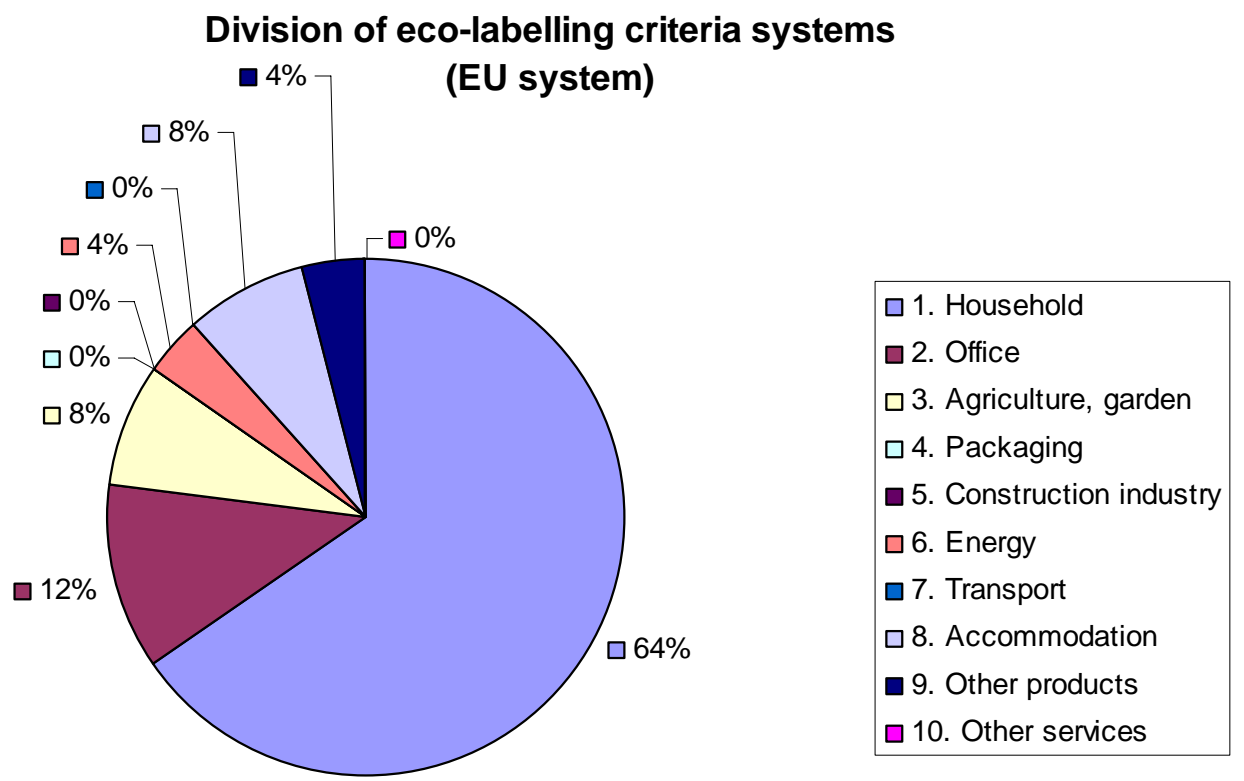

(Source: own edition)

Fig. 7. Division of eco-labelling criteria systems by product/service group (EU system)

man system has 15 criteria systems that are common with one other, and 8 criteria systems that are common with other two eco-labelling systems.

There are 2 criteria systems that are common in the Hungarian, EU and Nordic systems: Refrigerators and freezers, and General cleaning products. There are 5 criteria systems that are common in EU, Nordic and German systems: floorings, paints and varnishes, computers, heat pumps, lubricants. There are 2 criteria systems that are common in Hungarian, Nordic and German systems: photocopiers, printers, fax machines and multifunctional devices, toner cartridges.

There are 13 criteria systems that are common in Nordic and
German, 7 that are common in EU and Nordic, 2 that are common in Hungarian and Nordic, 2 that are common in Hungarian, German and 1 that is common in EU and German system.

\section{Summary and conclusions}

From the table it can be seen that the criteria systems do not show a uniform scheme but in all groups common elements can be found, except for one: for the construction industry no common criteria systems exist.

In my point of view it is an interesting result because it makes stronger my opinion that the first place of the number of construction industry (as it was mentioned above) in the Hungarian 


\section{Division of eco-labelling criteria systems \\ (Nordic system)}

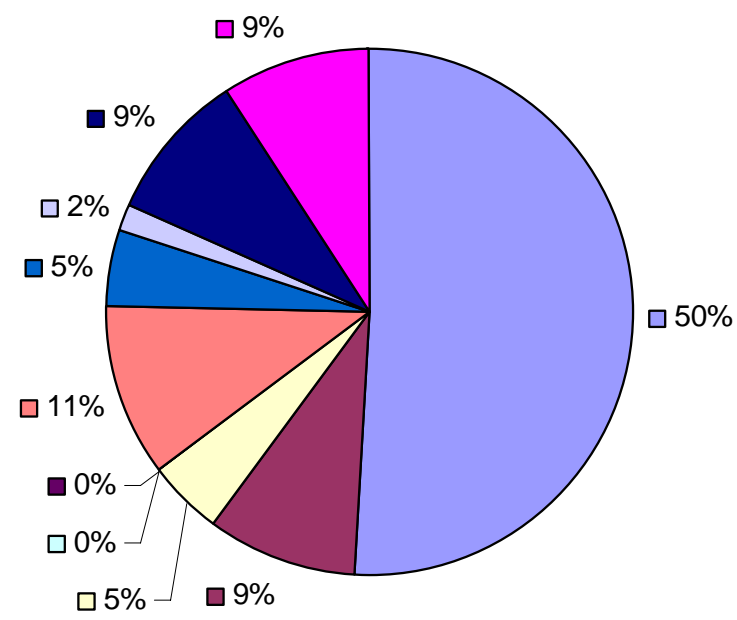

\begin{tabular}{|l|}
\hline 1. Household \\
$\square$ 2. Office \\
$\square$ 3. Agriculture, garden \\
$\square$ 4. Packaging \\
$\square 5$. Construction industry \\
$\square 6$. Energy \\
$\square$ 7. Transport \\
$\square$ 8. Accommodation \\
$\square 9$. Other products \\
$\square$ 10. Other services
\end{tabular}

(Source: own edition)

Fig. 8. Division of eco-labelling criteria systems by product/service group (Nordic system)

eco-labelling system is exaggerated.

Discussed the results, the Hungarian system has the least criteria system that is common with other systems, and the German has the most. But it is an interesting question: why? The answer may be that the Hungarian system has the least criteria systems and the German system has the most, but it also may be that the elaboration methodology of criteria systems is different than the other systems (as it was mentioned above).

Other result is that the most common criteria systems are in the household and office product groups. Interesting is that in the Hungarian system no common criteria systems exist in the following product groups: Transport, Energy, Other products, Other services.

Based on the results we can say that the criteria systems of the Hungarian eco-labelling system are different than the other systems. In order to grow the efficiency of the Hungarian ecolabelling system in the future it is necessary to reform the criteria making process with taking the 3 win model, information streams (Fig. 1, Fig. 2) and the results of the comparative analysis into consideration

\section{References}

1 Der Blaue Engel - Umweltzeichen mit Markenwirkung, Umweltbundesamt, 2007.

2 Global Ecolabelling Network (GEN), 2004. Information Paper. Introduction to eco-labelling.

3 Kósi K, Valkó L, Környezetmenedzsment, Budapest, 2006.

4 available at http://www. svanen.nu/

5 available at http://www.blauer-engel.de

6 available at http://www. kornyezetbarat-termek.hu/

7 available at http://ec.europa.eu/environment/ecolabel/index _

en.htm 